\title{
Peningkatan Keterampilan Siswa Sekolah Menengah Kejuruan Melalui Pelatihan Software Pemetaan
}

\author{
${ }^{1 *}$ Vidya Nahdhiyatul Fikriyah, ${ }^{1}$ Khusna Furoida \\ ${ }^{1}$ Fakultas Geografi, Universitas Muhammadiyah Surakarta \\ *Penulis korespondensi, email: vidya.n.fikriyah@ums.ac.id
}

(Received: 30 November 2020/Accepted: 21 December 2021/Published: 28 January 2021)

\begin{abstract}
Abstrak
Kecanggihan teknologi pemetaan di era digital sekarang ini semakin berkembang. Banyak software pemetaan bermunculan baik yang berbayar ataupun gratis. Keterampilan dalam pengoperasian software ini sangat penting bagi siswa Sekolah Menengah Kejuruan (SMK) jurusan kehutanan untuk menunjang materi pemetaan yang diajarkan di sekolah. Dalam rangka meningkatkan kompetensi siswa dalam menggunakan perangkat lunak pemetaan, maka kegiatan pengabdian ini dilaksanakan. Pengabdian yang dilakukan adalah dengan memberikan materi tentang Sistem Informasi Geografis (SIG) berupa konsep dan pengenalan ArcGIS, serta dilanjutkan dengan simulasi penggunaan software ArcGIS. Kuesioner juga dilaksanakan setelah pemaparan materi. Hasil kuesioner menunjukkan bahwa peserta mengapresiasi adanya kegiatan ini dan memberikan saran untuk dilakukan kegiatan pelatihan lanjutan baik tetap menggunakan ArcGIS maupun software pemetaan lain.
\end{abstract}

Kata Kunci : pelatihan, software, pemetaan, siswa

\begin{abstract}
The sophistication of mapping technology in today's digital era is increasingly developing. Many mapping software are availabe, either paid or free. Skills in operating mapping software are very important for students in Vocational High School (SMK) majoring in forestry to support the material taught in schools. In order to improve student competence in mapping with software, this community service activity was carried out. The activity was done by providing material about Geographic Information Systems (GIS) in the form of concepts and the introduction of ArcGIS, followed by a simulation on the use of ArcGIS software for mapping. The questionnaire was also carried out after the presentation. The results of the questionnaire showed that the participants appreciated this activity and provided suggestions for further training activities either still using ArcGIS or other mapping software.
\end{abstract}

Keywords : training, software, mapping, students

\section{Pendahuluan}

Sekolah Menengah Kejuruan (SMK) merupakan salah satu tingkatan dalam pendidikan menengah yang ada di Indonesia. Berdasarkan Peraturan Pemerintah Republik Indonesia Nomor 29 Tahun 1990, pendidikan menengah kejuruan mengutamakan penyiapan siswa untuk memasuki lapangan kerja serta mengembangkan sikap profesional yang ke depannya dapat membawa siswa SMK untuk lebih berpotensi pada lapangan kerja dan dukungan masyarakat termasuk dunia usaha/industri. Pendidikan kejuruan memang mendidik siswa secara khusus untuk bekerja dalam bidang tertentu (Lestari dan Siswanto, 2015) sehingga penyelenggara pendidikan menengah kejuruan perlu menerapkan kegiatan-kegiatan yang dapat mendukung siswa untuk meningkatkan kecakapan sesuai dengan kejuruan. 
SMK Bakti Nusa Bogor merupakan salah satu SMK yang memiliki kejuruan pada bidang kehutanan. Bidang kehutanan merupakan salah satu sektor yang paling banyak menyerap tenaga kerja pada tahun 2017 (Perdana, 2019). Hal tersebut tentunya akan menuntut SMK Bakti Nusa Bogor untuk dapat menghasilkan lulusan dengan kecakapan kehutanan yang mumpuni untuk dunia kerja. Salah satu kecakapan yang diperlukan dalam kehutanan adalah pemetaan.

Memasuki era digital dan revolusi industri 4.0 ini, software pemetaan menjadi semakin berkembang. Banyak software pemetaan yang ditawarkan terutama yang memanfaatkan fitur yang lengkap baik untuk database, pengolahan data spasial, pemrosesan citra satelit, hingga visualisasi data spasial. Pembelajaran pemetaan tidak cukup hanya mengandalkan pemahaman konsep pemetaan semata, namun diperlukan keahlian dan keterampilan salah satunya dalam menggunakan software.

Sejalan dengan perkembangan teknologi informasi dalam dunia pemetaan tersebut, maka diperlukan dukungan dari pihak akademik (sekolah dan universitas) untuk bisa menghasilkan lulusan yang handal tidak hanya memahami teori pemetaan namun juga terampil dalam mengoperasikan software pemetaan. Hal tersebut yang perlu diakomodasi oleh SMK. SMK seyogyanya mampu mengahasilkan lulusan yang siap kerja, terutama SMK jurusan kehutanan yang memasukkan pemetaan, Sistem Informasi Geografis (SIG), dan penginderaan jauh dalam kurikulum mereka.

Meskipun materi tentang pemetaan ini mejadi salah satu bagian materi mata pelajaran yang diajarkan di SMK Kehutanan, namun pemahaman siswa mengenai penggunaan software pemetaan masih kurang. Siswa belum dapat sepenuhnya mengerti akibat akses yang sulit karena software pemetaan yang berbayar sehingga proses pembelajaran untuk mata pelajaran tersebut menjadi kurang optimal, terutama pada penguasaan keterampilan pembuatan peta secara digital.

Kendala tersebut tidak selalu membatasi siswa untuk dapat memahami langkah mengenai pemetaan. Perkembangan ilmu pengetahuan dan teknologi (IPTEK) yang telah berubah di era ini banyak membuat perubahan yang dapat mendukung siswa untuk bisa lebih mudah dalam mencari sumber belajar, lebih banyak pilihan untuk menggunakan dan memanfaatkan ilmu pengetahuan dan teknologi, makin meningkatnya peran media dan multi media dalam kegiatan pembelajaran (Budiman, 2014). Pemanfaatan-pemanfaatan IPTEK yang dapat mereka terapkan dalam pencarian ilmu melalui pemetaan seperti mencari tutorial pemetaan melalui youtube, mencari sumber bacaan mengenai pemetaan melalui jurnal ilmiah, bahkan mengikuti kegiatan pelatihan online mengenai pemetaan sehingga mereka dapat berinteraksi langsung dengan pemateri terkait pemetaan. Selain ilmu mengenai pemetaan, melalui IPTEK pula siswa dapat menelusuri lebih lanjut mengenai bagaimana penerapan pemetaan dalam bidang-bidang lain diluar sekolah utamanya dunia kerja sehingga dapat mendukung tujuan dari pendidikan menengah kejuruan.

Berdasarkan paparan latar belakang dan permasalahan mitra yang telah dijabarkan tersebut, maka perlu dilakukan upaya kegiatan pengabdian berbentuk pelatihan. Sebagai bentuk pengabdian, maka Fakultas Geografi, Universitas Muhammadiyah Surakarta mengadakan pelatihan software pemetaan untuk siswa SMK Kehutanan Bakti Nusa, yang merupakan salah satu SMK yang memasukkan pemetaan, Sistem Informasi Geografis (SIG), serta penginderaan jauh sebagai materi dalam pembelajaran di kurikulumnya. Kegiatan yang dilaksanakan tersebut bertajuk "Pengenalan Dasar-dasar Sistem Informasi Geografis (SIG) dan Contoh- contoh Aplikasinya di Dunia Kerja".

Pemetaan adalah ilmu yang mempelajari kenampakan muka bumi yang menggunakan suatu alat dan menghasilkan informasi yang akurat (Ambarwati dan Johan, 2016). Informasi yang dapat dimunculkan melalui pemetaan utamanya dalam bidang kehutanan sangat bermacam-macam seperti pemetaan hutan, pemetaan luasan hutan, pemetaan lokasi sebaran hutan, pemetaan hasil pengukuran lapangan hutan dan lain-lain. Pemetaan telah mengalami perkembangan dari pemetaan dengan basis analog menjadi pemetaan digital. Pemetaan analog berupa tahapan pemetaan yang dilakukan melalui media-media cetak seperti kertas, spidol, penggaris, dan pendukung lainnya dalam melakukan penggambaran dalam pemetaan. Sedangkan, pemetaan digital merupakan proses kompilasi data dalam bentuk gambar digital (Lail dan Kusuma, 2015). 
Pemetaan digital dapat dilakukan melalui aplikasi pemetaan. Salah satu aplikasi yang dapat digunakan untuk pemetaan adalah SIG. SIG merupakan merupakan sistem informasi spasial yang digunakan untuk memproses data yang bergeoreferensi (Hamidi, 2007). Teknologi SIG mengintegrasikan operasi-operasi umum database, seperti query dan analisa statistik, dengan kemampuan visualisasi dan analisa yang unik yang dimiliki oleh pemetaan (Aini, 2007). Kemampuan dari SIG tersebutlah yang membuat SIG dapat dimanfaatkan oleh berbagai macam bidang dan kalangan untuk berbagai tujuan.

Penerapan SIG dalam bidang kehutanan seperti perlindungan hutan yang dapat dilakukan melalui perubahan luas hutan, prediksi, lokasi, arah, tingkat penyebaran, dan intensitas kebakaran hutan melalui SIG (Berutu, 2012; Nursoleha, 2014). SIG yang dapat digunakan untuk identifikasi lahan-lahan yang terdapat tumbuhan dan lahan-lahan yang bisa dilakukan reboisasi (Setiabudi dan Pradika, 2010). SIG juga dapat digunakan untuk pemetaan yang memberikan informasi mengenai komoditi hasil pertanian, perkebunan, dan kehutanan yang dapat memepermudah masyarakat dan pemerintah untuk mencari lokasi, harga, produksi dan informasi lainnya yang terkait (Suryamen, 2017). Tentunya dari contoh-contoh penerapan SIG dalam kehutanan dapat disimpulkan bahwa akan sangat bermanfaat jika siswa SMK kehutanan mengetahui lebih lanjut mengenai apa itu pemetaan dan SIG.

SIG yang telah berkembang memiliki banyak software seperti ArcGIS, QGIS, ER Mapper, dan lain-lain. ArcGIS merupakan salah satu software SIG yang lebih dikenal secara luas. ArcGIS dikeluarkan oleh Environmental Systems Research Institute (ESRI) dengan susunan aplikasi didalamnya berupa ArcMap, ArcView, ArcScene, dan ArcCatalog. Beberapa keunggulan yang dimiliki oleh ArcGIS menurut Booth dan Mitchell (2001) yaitu ArcGIS memiliki sistem susunan yang lengkap sehingga dapat digunakan oleh baik oleh pengguna sesuai dengan fungsinya, ArcGIS juga telah menyediakan fasilitas pendukung dari fungsi-fungsi dalam aplikasinya untuk mendukung berbagai keperluan utamanya dalam penerapan SIG. ArcGIS juga mampu mengolah beberapa analisis sekaligus dengan menggunakan fasilitas Model Builder, serta alasan paling menarik dalam penggunaan ArcGIS yaitu karena ArcGIS memiliki beberapa kemudahan yang dapat digunakan pengguna utamanya dalam proses pemetaan seperti kemudahan dalam mengonversi peta analog menjadi peta digital, proses input data yang dapat dilakukan melalui banyak jenis data, serta mudahnya dalam melakukan modifikasi desain dan tampilan peta. Selaras dengan keunggulan yang dimiliki oleh ArcGIS, ArcGIS juga memiliki kekurangan dimana fiturfitur ArcGIS hanya dapat diakses secara bebas dengan biaya sehingga kendala utama dalam penggunaan ArcGIS biasanya terkait pada kendala biaya.

Kegiatan pelatihan ini bertujuan untuk peningkatan kompetensi dan keterampilan siswa SMK kehutanan dalam bidang pemetaan. Tidak hanya itu, kegiatan ini penting dilaksanakan sebagai media pembelajaran tambahan yang memberikan kesempatan kepada siswa untuk memperluas wawasan tentang dunia pemetaan khususnya penggunaan software ArcGIS. Hal ini bermanfaat untuk menunjang proses pembelajaran di kelas serta mendukung kompetensi alumni ketika bekerja di bidang yang memerlukan peta baik sebagai sumber data, alat perencanaan, maupun produk kerja.

\section{Metode}

Pelaksanaan pengabdian masyarakat berbasis pelatihan software dipilih berdasarkan analisa kebutuhan mitra. Tim pengabdi kemudian menawarkan solusi berupa pemaparan materi berupa konsep sekaligus demonstrasi pembuatan peta secara digital menggunakan ArcGIS secara langsung. Selama kegiatan berlangsung, peserta tidak dipungut biaya apapun, dan kegiatan ini juga dapat diakses oleh seluruh siswa SMK Kehutanan. Siswa SMK Kehutanan dipilih menjadi sasaran pengabdian karena kesesuaian materi yang akan diberikan dengan materi yang diajarkan di sekolah. Dengan demikian, diharapkan kegiatan pelatihan akan memberikan manfaat yang sesuai dengan yang dibutuhkan oleh siswa.

Pelaksanaan pengabdian dilakukan secara daring menggunakan media zoom untuk dapat menjangkau peserta yang jauh lokasinya dengan pengabdi, serta sebagai bentuk pencegahan 
penularan penyakit COVID-19. Melalui media daring ini diharapkan peserta menjadi lebih fokus dalam belajar serta tidak sungkan dalam bertanya atau menjawab pertanyaan dari pengabdi saat sesi pemaparan dilakukan. Melalui pelatihan daring, siswa juga tidak memerlukan fasilitas khusus untuk dapat mengikuti pelatihan. Peserta hanya memerlukan kuota internet dan alamat ruang diskusi zoom yang telah disampaikan oleh pengabdi sebelumnya.

Pelaksanaan kegiatan pengabdian dilakukan dalam beberapa tahapan, yang secara umum dapat dilihat pada Gambar 1.

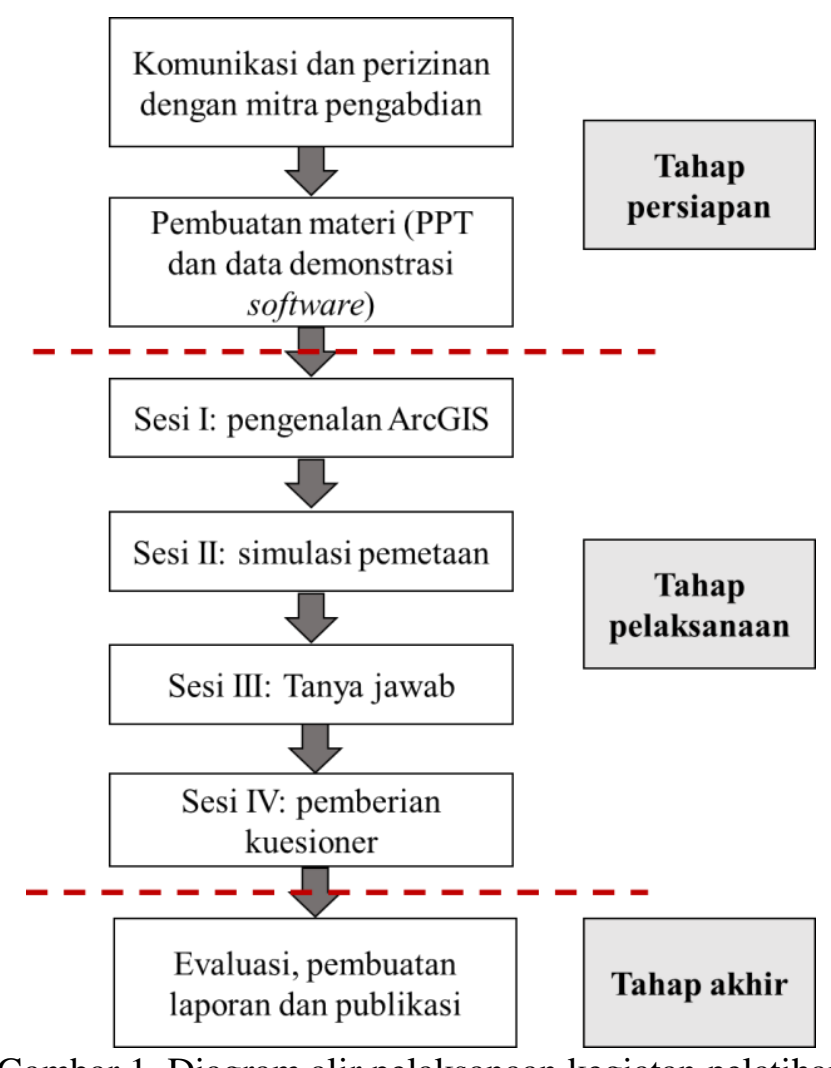

Gambar 1. Diagram alir pelaksanaan kegiatan pelatihan

Kegiatan diawali dengan melakukan komunikasi dengan pihak mitra untuk mengetahui permasalahan dan kebutuhan mitra agar materi pengabdian dapat menjadi tepat sasaran. Selanjutnya, pembuatan materi yang disesuaikan dengan kebutuhan mitra. Data untuk demonstrasi juga disiapkan dan diuji coba agar pelatihan dapat berjalan lancar.

Tahapan selanjutnya adalah pelaksanaan kegiatan pengabdian yang mana terbagi menjadi empat sesi, masing- masing adalah sesi pemaparan materi Sistem Informasi Geografis (SIG) dan pengenalan ArcGIS, simulasi pembuatan peta dengan ArcGIS, sesi tanya jawab, dan terahir adalah sesi pemberian kuesioner kepada peserta untuk mendapatkan masukan dan saran dari peserta untuk pelatihan selanjutnya. Sesi tanya jawab diadakan untuk memberikan kesempatan kepada peserta jika masih ada yang belum memahami bagian dari materi. Pertanyaan juga terbuka bagi peserta yang ingin memperdalam materi pemetaan ini.

Untuk mengetahui respon sejauh mana pemahaman peserta dan saran dari peserta untuk kegiatan selanjutnya, evaluasi dilakukan dengan menyebarkan kuesioner yang diisi oleh peserta. Peserta mengisi kuesioner menggunakan Google form yang diberikan setelah sesi. Pertanyaan dalam kuesioner tersebut untuk menilai tingkat kepuasan siswa terhadap proses pelatihan. Secara khusus kuesioner tersebut berisi pertanyaan tentang identitas peserta, penerimaan materi oleh peserta, kesesuaian materi dengan kebutuhan peserta, serta saran untuk kegiatan mendatang. Rincian pertanyaan kuesioner beserta pilihan jawaban dapat dilihat pada Tabel 1. Kegiatan selanjutnya adalah pembuatan laporan dan penulisan naskah untuk publikasi. 
Tabel. 1 Pertanyaan dalam kuesioner

\begin{tabular}{|c|c|c|}
\hline No & Nama & Pilihan jawaban atau pertanyaan terbuka \\
\hline 1. & Kelas & X, XI, XII \\
\hline 2. & Nomor Induk & pertanyaan terbuka \\
\hline 3. & Jurusan & pertanyaan terbuka \\
\hline 4. & $\begin{array}{l}\text { Bagaimana menurut Saudara materi yang } \\
\text { diberikan? }\end{array}$ & $\begin{array}{l}\text { Sangat dapat diterima dengan baik, } \\
\text { dapat diterima dengan baik, cukup dapat } \\
\text { diterima, kurang dapat diterima, dan sangat } \\
\text { kurang dapat diterima }\end{array}$ \\
\hline 5. & $\begin{array}{l}\text { Apakah materi sesuai dengan yang } \\
\text { Saudara butuhkan? }\end{array}$ & Sesuai dan tidak sesuai \\
\hline 6. & $\begin{array}{l}\text { Apa materi yang Saudara sarankan untuk } \\
\text { program ini }\end{array}$ & pertanyaan terbuka \\
\hline
\end{tabular}

Tahapan terakhir adalah kegiatan evaluasi yang didasarkan pada masukan dan saran hasil pengumpulan kuesioner. Data tersebut dianalisis secara deskriptif kuantitatif untuk mengetahui persentase peserta yang memahami materi dan berpendapat bahwa materi yang disampaikan cocok atau tidak dengan kebutuhan dari peserta. Khusus untuk bagian saran, data yang masuk tersebut dilakukan kodifikasi, yakni pemberian kode atau label untuk setiap kata kunci dari saran yang diberikan. Semua saran yang masuk tersebut selanjutnya dikelompokkan berdasarkan kata kuncinya agar dapat ditemukan rangkuman dan dianalisis.

\section{Hasil dan Pembahasan}

Kegiatan pengabdian dengan sasaran siswa SMK Kehutanan ini merupakan bagian dari rangkaian kegiatan pengabdian bertema aplikasi SIG. Secara lengkap pengabdian dilakukan bersama pengabdi lain selama dua hari dari 20- 21 Juli 2020. Khusus untuk pelatihan dan demonstasi penggunaan ArcGIS, kegiatan dilaksanakan satu hari pada tanggal 20 Juli 2020 selama 90 menit mulai dari pukul 14.30- 16.00. Kegiatan diberi judul Workshop Penggunaan SIG Dasar Menggunakan ArcGIS. Kegiatan pengabdian ini diikuti oleh 33 siswa SMK Kehutanan Bakti Nusa. SMK Bakti Nusa merupakan sekolah kejuruan dengan bidang keahlian agribisnis dan agroteknologi untuk program keahlian kehutanan dan paket keahlian teknik inventarisasi dan pemetaan hutan. Pelatihan juga didampingi oleh guru sehingga guru dapat mengetahui materi apa yang diberikan dan diharapkan nantinya dapat menindaklanjuti penjelasan yang didapat dari kegiatan ini untuk tambahan materi di kelas.

Hasil kegiatan pengabdian ini secara garis besar mencakup dua bagian materi, yakni:

a. Pemaparan materi tentang SIG dan pengenalan ArcGIS (Gambar 2), meliputi kemampuan ArcGIS, kelebihan dan kekurangan ArcGIS, alur pemrosesan data spasial hingga visualisasi, penjelasan pemrosesan dasar, berbagai macam teknik overlay, pelacakan data (query), teknik simbolisasi berdasarkan karakteristik data, dan layout peta.

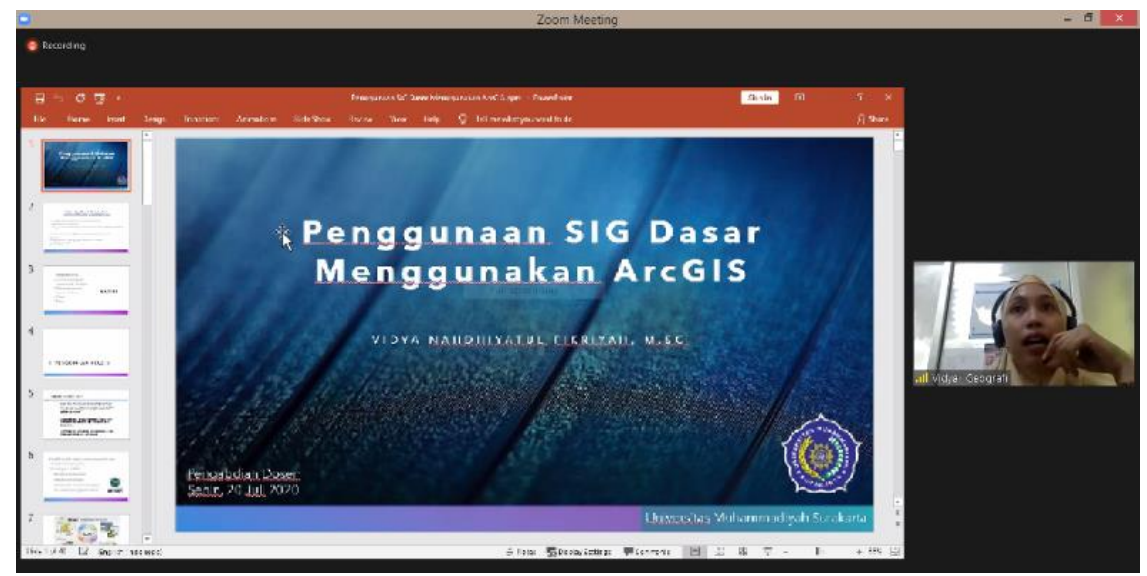

Gambar 2. Pemaparan materi tentang Sistem Informasi Geografis dan pengenalan ArcGIS. 
b. Demonstrasi pemetaan menggunakan ArcGIS (Gambar 3), meliputi input data spasial, pembuatan data spasial (georeferencing dan digitasi), konversi data, pemrosesan dasar (intersect dan buffer), query, pembuatan simbol peta, dan layout peta yang lengkap sesuai dengan komponen yang diperlukan (judul, skala, legenda, sumber, dan garis koordinat). Terakhir adalah proses penyimpanan peta dan konversinya menjadi format .jpeg dan .pdf.

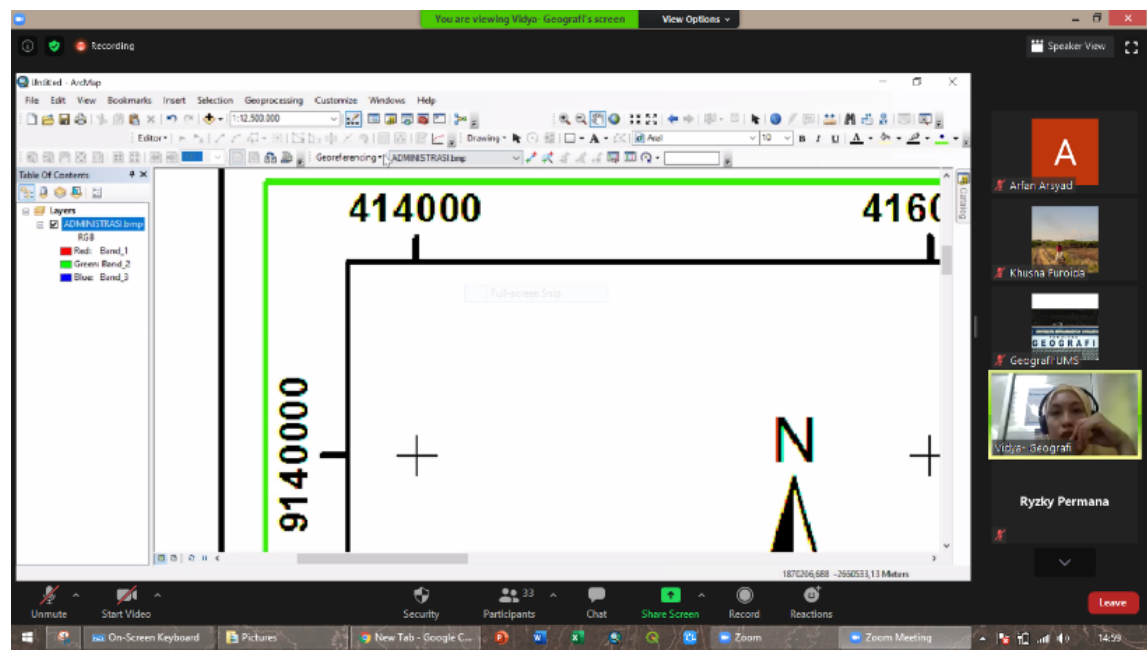

Gambar 3. Demonstrasi proses pemetaan menggunakan ArcGIS

Berdasarkan interaksi pengabdi dengan peserta, diketahui bahwa siswa telah mendapatkan mengenal tentang pemetaan, seperti tentang pembacaan peta, penggunaan software ArcGIS, dan interpretasi citra penginderaan jauh. Namun demikian, materi yang dipelajari tersebut masih belum mencakup seluruhnya, sehingga ini menjadi aspek yang dapat dilengkapi melalui kegiatan pelatihan ini. Peserta juga nampak bersemangat mengikuti kegiatan yang terlihat dari pertanyaan yang diajukan. Pertanyaan tersebut mencakup penjelasan materi yang telah diberikan, serta pertanyaan tentang software apa saja yang perlu dikuasai oleh pembuat peta atau khususnya surveyor.

Menurut hasil kusioner tentang profil peserta (Gambar 4), diketahui bahwa sebagian besar peserta berada di kelas XI (61\%) dan sisanya berasal dari kelas XII, yang berarti bahwa sebagian peserta belum mendapatkan materi pemetaan tingkat lanjut di sekolah.

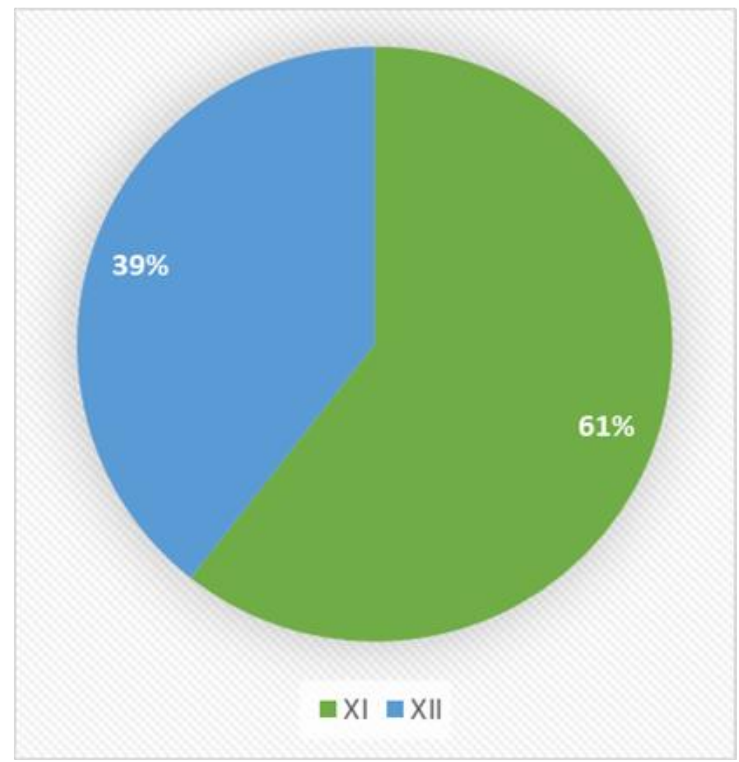

Gambar 4. Profil peserta pengabdian berdasarkan kelas. 
Berkaitan dengan respon peserta dalam menerima materi yang diberikan (Gambar 5), didapatkan hasil bahwa $49 \%$ peserta merasa bahwa materi dapat diterima dengan sangat baik, di mana nilai lainnya terbagi menjadi $24 \%$ dan $21 \%$ untuk dapat diterima dan cukup dapat diterima dengan baik secara berurutan. Nilai ini menunjukkan bahwa baik tingkat kedalaman materi dan penyampaian materi telah dilaksanakan dengan baik sehingga kemudian peserta materi tersebut dapat pula diterima dengan baik oleh peserta.

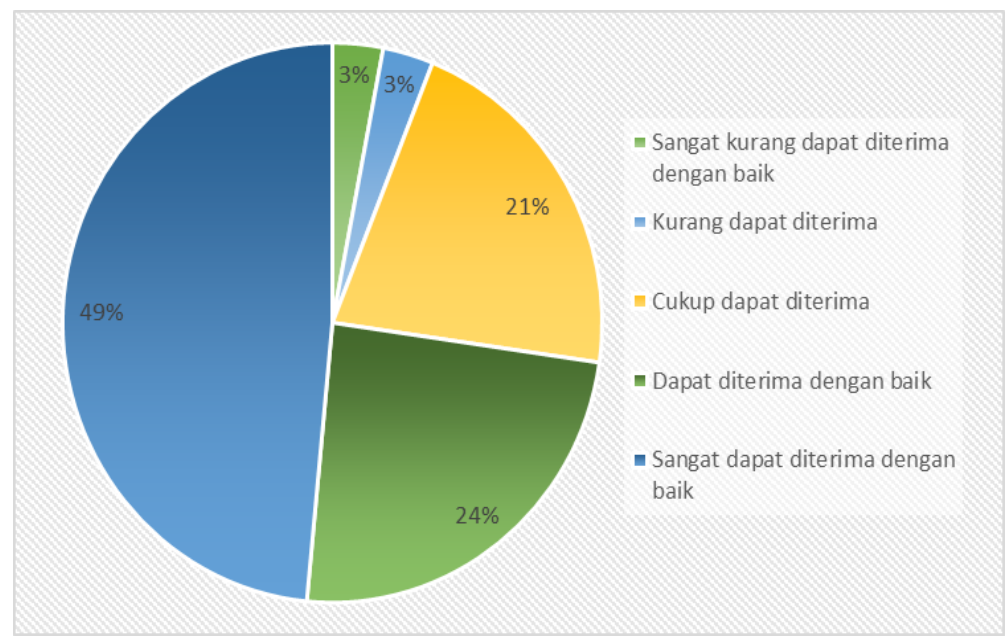

Gambar 5. Respon penerimaan materi oleh peserta

Respon sangat positif juga diberikan oleh peserta berdasarkan hasil kuesioner mengenai kesesuaian materi dengan kebutuhan peserta, di mana seluruh peserta (100\%) menyatakan bahwa materi yang disampaikan sesuai dengan apa yang diperlukan oleh peserta baik oleh siswa kelas XI dan kelas XII. Respon ini mengindikasikan bahwa kegiatan komunikasi dengan pihak mitra sebelum pengabdian untuk mencari informasi permasalahan dan kebutuhan mitra dapat diartikan dengan baik oleh pengabdi dalam bentuk materi dan demonstrasi pemetaan.

Selanjutnya untuk saran yang diberikan oleh peserta (Gambar 6), meskipun banyak dari peserta yang telah merasa cukup dengan pelatihan yang diberikan (31\%), sebesar masing- masing $15 \%$ dari peserta berpendapat bahwa perlu adanya pelatihan dan materi tambahan untuk SIG secara umum dan ArcGIS tingkat lanjut. Sebanyak $18 \%$ peserta juga menyatakan perlu dibuat materi penguasaan kegiatan survei di lapangan seperti penggunaan alat Global Positioning System $(G P S)$. Sisa dari saran yang diberikan masuk pada pelatihan dengan software lain seperti Quantum GIS (QGIS), drone, dan lanjutan visualisasi peta yang baik.

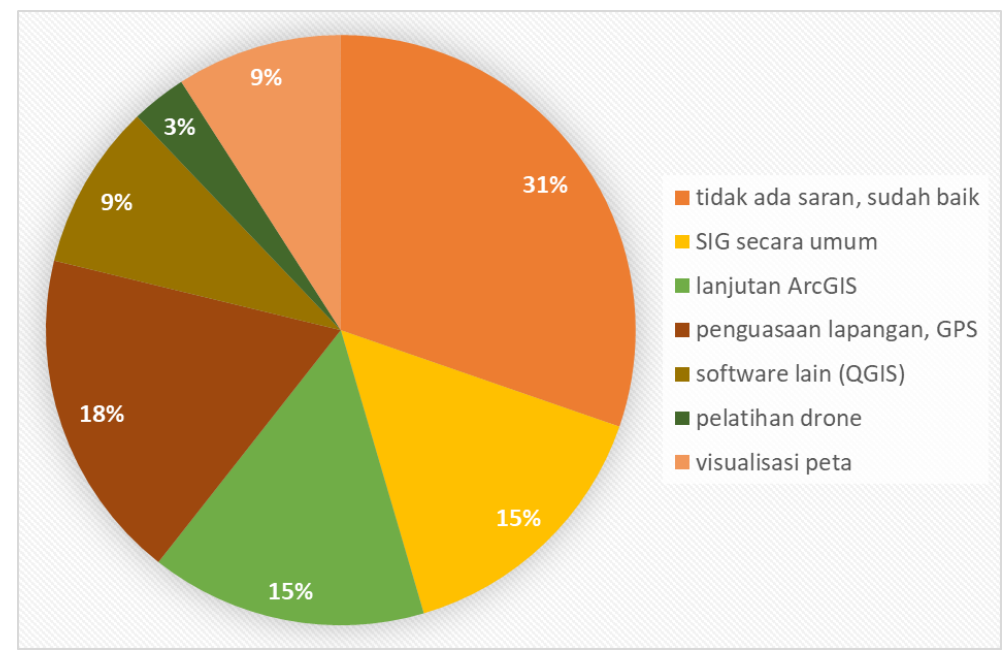

Gambar 6. Saran kegiatan selanjutnya dari peserta. 
Diharapkan pelatihan ini dapat dilanjutkan kembali di tahun mendatang dengan tetap menggunakan software ArcGIS, namun dengan pelatihan fitur-fitur lainnya terutama yang berkaitan dengan aplikasi kehutanan. Hal ini akan memberikan informasi tidak hanya bagi siswa tetapi juga guru, tentunya masih dengan memanfaatkan media daring untuk dapat menjangkau jumlah peserta yang banyak dan lokasinya yang jauh, sehingga kegiatan pengabdian menjadi lebih interaktif dan dapat menunjang pemebelajaran siswa di sekolah.

\section{Simpulan}

Berdasarkan hasil kegiatan pengabdian yang telah dilaksanakan dan dijelaskan sebelumnya, maka dapat disimpulkan bahwa secara umum kegiatan pengabdian masyarakat ini menambah wawasan siswa dalam pembuatan peta, serta memberikan pengalaman belajar melihat simulasi pembuatan peta secara digital menggunakan software. Kegiatan ini berdampak positif bagi terlaksananya pembelajaran pemetaan terutama bidang kehutanan yang lebih efektif.

Selanjutnya berdasarkan saran yang dikumpulkan dari kuesioner, diharapkan perlu adanya kegiatan tindak lanjut setelah pelatihan ini, yakni pelatihan lanjutan Sistem Informasi Geografis secara umum, termasuk pelatihan ArcGIS tingkat lanjut, penggunaan alat survei lapangan, dan pelatihan pemetaan dengan software, yakni QGIS. Pemberdayaan siswa yang lebih banyak melakukan praktek (workshop) juga patut untuk direncanakan, agar peserta dapat lebih memahami tahapan pembuatan peta secara langsung dan bisa mendapatkan saran perbaikan dari pemberi materi.

\section{Persantunan}

Penulis mengucapkan terima kasih kepada pihak Sekolah Menengah Kejuruan Kehutanan Bakti Nusa yang telah memberikan kesempatan menjadi mitra dalam kegiatan pengabdian ini. Selain itu, apresiasi juga diberikan kepada Fakultas Geografi, Universitas Muhamadiyah Surakarta yang telah memberikan dukungan demi terselenggaranya program ini secara baik.

\section{Referensi}

Aini, A. (2007). Sistem Informasi Geografis Pengertian dan Aplikasinya. Diakses dari http://stmik. amikom. ac. id/[Diakses 24 Maret 2013].

Ambarwati, W., \& Johan, Y. (2016). Sejarah dan Perkembangan Ilmu Pemetaan. Jurnal Enggano, 1(2), 80-82.

Berutu, D. S., \& Nurman, A. (2012). Aplikasi Penginderaan Jauh dan Sistem Informasi Geografis Dalam Mengkaji Perubahan Luas Hutan Di Kabupaten Kuantan Singingi (Riau) Tahun 20002010. Jurnal Geografi, 5(2), 189-198.

Booth, B., \& Mitchell, A. (2001). Getting Started With ArcGIS.

Budiman, H. (2017). Peran Teknologi Informasi Dan Komunikasi Dalam Pendidikan. Al-Tadzkiyyah: Jurnal Pendidikan Islam, 8(1), 31-43.

Hamidi, H. (2012). Aplikasi Sistem Informasi Geografis Berbasis Web Penyebaran Dana Bantuan Operasional Sekolah. Jurnal Masyarakat Informatika, 2(3), 1-14.

Lail, J. (2015). Peta Digital Dusun Sentono. Asian Journal of Innovation and Entrepreneurship, 4(01), 50-53.

Lestari, I., \& Siswanto, B. T. (2016). Pengaruh Pengalaman Prakerin, Hasil Belajar Produktif dan Dukungan Sosial Keluarga Terhadap Kesiapan Kerja Siswa SMK. Jurnal Pendidikan Informatika Dan Sains, 4(1).

Nursoleha, P., Banowati, E., \& Parman, S. (2014). Zonasi Tingkat Kerawanan Kebakaran Hutan di Taman Nasional Gunung Ciremai (TNGC) Berbasis Sistem Informasi Geografis (SIG). GeoImage, 3(1). 
Perdana, N. S. (2019). Analisis Permintaan Dan Penawaran Lulusan SMK Dalam Pemenuhan Pasar Tenaga Kerja. Refleksi Edukatika: Jurnal Ilmiah Kependidikan, 9(2).

Peraturan Pemerintah Republik Indonesia No. 29 Tahun 1990 Tentang Pendidikan Menengah.

Setiabudi, F., \& Pradika, M. F. Sistem Informasi Geografis Hutan Penelitian Petak 93 Gunungkidul. Tugas Akhir Jurusan Teknik Informatika STMIK AMIKOM Yogyakarta.

Suryamen, H., \& Hsb, H. (2017). Pembangunan Sistem Informasi Komoditi Berbasis WebGIS untuk Pertanian Perkebunan Dan Kehutanan Daerah Tanjung Raya Maninjau. Prosiding Semnastek.

\section{(c) $(i)(8) \Theta$}

(C) 2021 by the authors. Submitted for possible open access publication under the terms and conditions of the Creative Commons Attribution (CC-BY-NC-ND) license (http://creativecommons.org/licenses/by/4.0/). 